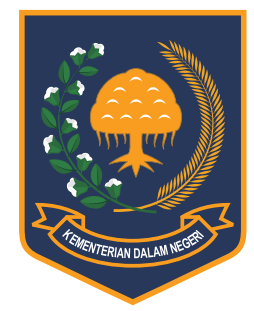

Jurnal Bina Praja 8 (2) (2016): 263-275

Jurnal Bina Praja

e-ISSN: 2503-3360 | p-ISSN: 2085-4323

Accreditation Number

735/AU2/P2MI-LIPI/04/2016

http://jurnal.kemendagri.go.id/index.php/jbp/index

\title{
E-GOVERnMENT MATURITY MODEL BASED ON SYSTEMATIC REVIEW AND META-ETHNOGRAPHY APPROACH
}

\author{
Darmawan Napitupulu ${ }^{1}$ \\ ${ }^{1}$ Research Center for Quality System and Testing Technology (P2 SMTP) \\ Indonesian Institute of Sciences (LIPI) \\ Gedung 417, Jl. Kw. Puspiptek, Muncul, Setu, Kota Tangerang Selatan, Banten 15314, Indonesia
}

Received: 25 June 2016; Accepted: 6 October 2016; Published online: 30 November 2016

DOI: $10.21787 / \mathrm{jbp} .08 .2016 .263-275$

\begin{abstract}
Maturity model based on e-Government portal has been developed by a number of researchers both individually and institutionally, but still scattered in various journals and conference articles and can be said to have a different focus with each other, both in terms of stages and features. The aim of this research is conducting a study to integrate a number of maturity models existing today in order to build generic maturity model based on e-Government portal. The method used in this study is Systematic Review with meta-ethnography qualitative approach. Meta-ethnography, which is part of Systematic Review method, is a technique to perform data integration to obtain theories and concepts with a new level of understanding that is deeper and thorough. The result obtained is a maturity model based on e-Government portal that consists of 7 (seven) stages, namely web presence, interaction, transaction, vertical integration, horizontal integration, full integration, and open participation. These seven stages are synthesized from the 111 key concepts related to 25 studies of maturity model based e-Government portal. The maturity model resulted is more comprehensive and generic because it is an integration of models (best practices) that exists today.
\end{abstract}

Keywords: e-Government, maturity model portal, meta-ethnography.

\section{INTRODUCTION}

Today, e-Government is a very important issue related to the use of Information and Communication Technology (ICT) by government agencies in providing services to the community electronically (Nilashi, 2012: 194). Ideally, the development of e-Government is expected to help improve the interaction between government, public, and businesses to encourage economic and political developments (Istiyanto \& Sutanta, 2012: 137) since e-Government is intended to shorten the distance between the government as the provider of public services (public service provider) and public or business as users of public services (public service customer). This causes the role of e-Government or electronic-based government to be more important for all decision makers on governing (Yalia, 2011: 66). Even, the adoption of
e-Government in its implementation has increased in various countries, but at the same time, the speed of e-Government adoption varies from country to country (Furuholt \& Fath, 2008: 1). When viewed deeper to the extent on the implementation of e-Government in developing countries, especially in Indonesia, the majority of government agencies in Indonesia is still in the second phase (Safitri, 2013: 42 ), which is the maturation phase of 4 (four) stages of the development of e-Government if referred to maturity model on the Presidential Instruction No 3 of 2003, namely:

1. The preparation stage, in the form of the presence of the site that contains basic information needed by public.

2. The maturation phase, in the form of interaction between the government and the public.

3. The stabilization stage, in the form of online government service transactions.

\footnotetext{
* Corresponding Author

Phone : +6281314060258

Email : darwan.na70@gmail.com
} 
4. The deployment phase, in the form of the integration of services that connects the government with the public and businesses.

If compared with developed countries, Indonesia is far behind in terms of the implementation of e-Government where the implementation of e-Government in developed countries is already in the final stage, namely the deployment phase (Shahkooh et al., 2008: 3). While Indonesia and other developing countries are still at the initial stage or phase of development of e-government system.

The goal of the development of e-Government in Indonesia as stipulated in Presidential Instruction (Inpres) No 3 of 2003 is to improve the quality of public service and public participation in the formulation of state policy. But until now, it can be said the implementation of e-Government in Indonesia is still far from expected and has been slow (Napitupulu, 2015: 232). This is demonstrated again with the condition of the low level of accessibility of government websites, in which according to the research by the Ministry of Communication and Information (2004) that of 224 government websites in 2004, there are $10 \%$ websites that cannot be opened. It is added by a research of Hendriawan (2008: 53) which reported that of 402 websites at the local level, there are 65 sites that are not accessible or $16 \%$ of the total existing sites. Even, based on the result of a national survey by the Ministry of Communication and Information in the form of rankings of e-Government in Indonesia (PEGI) in 2012, there are only six local governments of the total 497 districts/cities that are considered successful in implementing e-Government while at the provincial level, the implementation of e-Government still gets an average value of less (PEGI, 2014). On the international stage, Indonesia is far below other countries in the adoption of e-Government. Based on the Waseda e-Government Ranking 2015, it appears that Indonesia is ranked 29 of 38 countries adopting e-Government (Waseda, 2015: 2). In line with this, the rating of e-Government by the United Nations in 2014 at the ASEAN level shows that Indonesia ranked 6 out of a total of 11 countries, far below Malaysia and Vietnam (UN, 2014: 129).

With the condition described above, e-Government maturity model based on portal that is stated in Inpres No 3 of 2003 which is guiding the development of e-Government in Indonesia is the adoption of a maturity model of the United Nations (UN, 2012). Today, many maturity models, which are best practices, have been developed by individuals and organizations that aim to assess the maturity of e-Government portal, but still scattered in various journals and conference articles. Besides, e-Government maturity models have turned out to be of different focus in terms of its phases and features (indicator). Furthermore, maturity models can include several stages but ignore the stages of other models (Abdoullah et al., 2014: 87) so that each model has its advantages and disadvantages. Each one of them, including maturity models, contained in Presidential Instruction No 3 of 2003. The research question that can be proposed is how is the generic e-Government maturity model based on best practice maturity models that exist today?

Therefore, the aim of this research is to conduct a study to integrate a number of e-Government maturity models (best practice) that exist today to generate a maturity model that is more comprehensive and generic through synthesis process with a meta-ethnography qualitative approach. The result of this research in the form of a maturity model can be proposed as a policy recommendation that will be expected to be a guideline to encourage government agencies in increasing the maturity of e-Government to a higher stage.

\section{MeTHOD}

The method used by the researcher is a Systematic Review with a qualitative approach called Meta-Ethnography. Systematic Review is a study method for the identification, evaluation, and interpretation of all relevant research results related to a specific research question, a specific topic, or a phenomenon of interest (Kitchenham, 2004: 1). An individual study is a form of primary study, whereas Systematic Review is secondary study. Systematic Review is a synthesis of primary research studies that presents a particular topic with the formulation of specific and clear questions, the search methods that are explicit and reproducible, involves a process of critical examination in the selection of the study, and communicates the results and their implications (Green, 2005: 272 ). Thus, Systematic Review will be very useful to integrate a variety of relevant research results, so that the facts presented to policy makers become more comprehensive and balanced.

As in the individual study, principally the Systematic Review research begins with a research protocol of Systematic Review and the next stage is conducting Systematic Review research. Sequentially, Systematic Review research process can be presented in Table 1 where the first step of Systematic Review is to identify problems in the form of research questions in a clear, unambiguous, and structured way. Having defined the research questions, then developed the Systematic Review protocols. However, the most important part in the process of Systematic Review is the selection of relevant research results or significantly related to the research question. Therefore, the selection 
Table 1.

Systematic Review Sequence Process

\begin{tabular}{|c|c|}
\hline Process Stage & Purpose \\
\hline Identification of research questions & Transforming the problem into research questions \\
\hline Developing research protocol of Systematic Review & Providing guidance in conducting Systematic Review \\
\hline $\begin{array}{l}\text { Determining the location of research results database as } \\
\text { the search area }\end{array}$ & Providing the limitation of the search area for relevant research results \\
\hline Selection of relevant research results & Collecting research results that are relevant to the research question \\
\hline Choose quality research results & $\begin{array}{l}\text { Conducting exclusion and inclusion towards the research that will be included } \\
\text { in a systematic review based on the quality }\end{array}$ \\
\hline Extraction of data from individual studies & Extraction of data from individual studies \\
\hline $\begin{array}{l}\text { Synthesis of the results with the meta-analysis method (if } \\
\text { possible) or the narrative method (if not possible) }\end{array}$ & $\begin{array}{l}\text { Synthesizing the results with the meta-analysis technique (forest plot) or } \\
\text { narrative technique (meta-synthesis) }\end{array}$ \\
\hline Presentation of results & $\begin{array}{l}\text { Writing down the results in the report document of the systematic review } \\
\text { result }\end{array}$ \\
\hline
\end{tabular}

Source: Perry \& Hammond, 2002

of a qualified study becomes a crucial step in Systematic Review. If the study included in the Systematic Review is of poor quality, then the result of the Systematic Review will be invalid as well. The selection of the study that is qualified and not bias is the validity key of Systematic Review. The term "garbage in garbage out" is applicable to the Systematic Review research method.

World Health Organization (2004) suggests that there is a hierarchy of methods of presenting the facts to the user as follows: (i) innovation in the realm of theory, methodology, and basic research, (ii) single research report and articles, (iii) synthesis of the research (systematic review), (iv) an input for policy makers (actionable message: policy briefs and policy papers). Hierarchically, the methodology ladder of "research into action" to be easily used by policy-makers, can be illustrated in Figure 1.

From Figure 1, seen that from an individual or single study, to be able to be used by policy makers, it still has to go through two more stages, namely synthesis (systematic review) and packaging of research results into a message that is easily understood by policy makers (actionable messages) in the form of policy recommendations.

Therefore, in this study by using a synthesis process of systematic review as a research method that presents the facts to the results of research in addition to generating new research findings, this study also provides recommendations to the relevant policy makers related to best practice models.

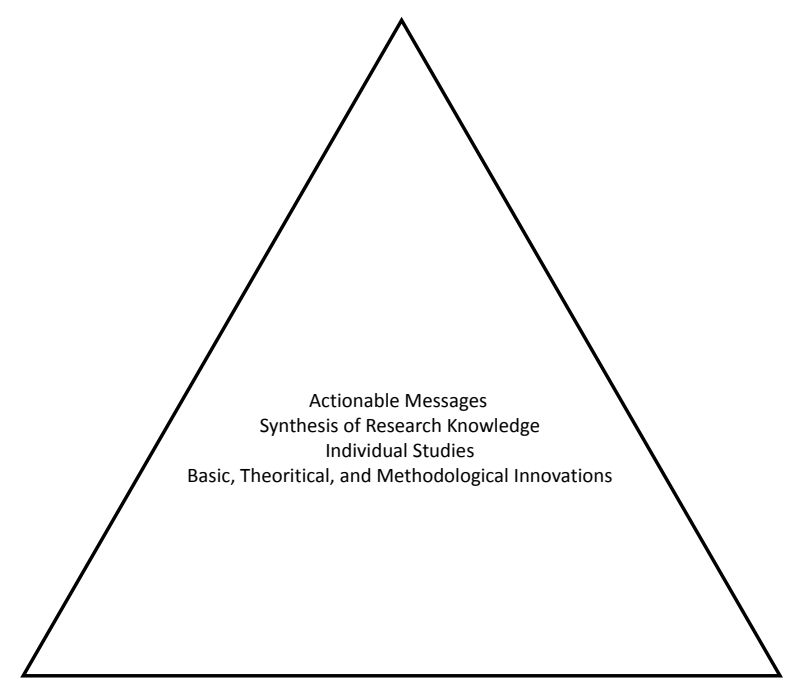

Figure 1. Hierarchy of Research Methodology for Policy Input

Source: WHO, 2004 
Table 2.

Seven Steps of Meta-Ethnographic

7 Steps of Noblit and Hare's Meta-Ethnography

1 Preparation - Identify a research topic for the synthesis process

2 Determine the relevant study - Determine the study that is relevant to the research interests and find the literature on scientific databases

3 Read and review the study - read repeatedly and assess and mark the concept of metaphor

4 Determine the relation between studies - Jointly include the studies and determine the relationships

5 Translate each study - Transaction by comparing each other's concept or metaphor

6 Synthesis of the translation result - Compile the entire study

$7 \quad$ Express the synthesis - naming the synthesis result

Source: Noblit \& Hare, 1988

\section{QUALITATIVE APPROACH}

An analogy with research methodology in general, where there are quantitative and qualitative methods, in a systematic review there are also quantitative and qualitative methods (Siswanto, 2010). The quantitative method of systematic review is used to synthesize the results of research with a quantitative approach. The quantitative approach in the systematic review is called metaanalysis. Meanwhile, in a systematic review, the qualitative method is used to synthesize the results of research that are of qualitative description called meta-synthesis. By definition, a meta-synthesis is a technique to perform data integration theory and concepts to get a new or deeper levels and thorough of understanding (Perry \& Hammond, 2002). In conducting a meta-synthesis, there are two approaches namely meta-aggregation and meta-ethnography (Lewin, 2008). In the metaaggregation, synthesis aims to answer research questions in a way summarizes the results of the study (summarizing). While the meta-ethnography, synthesis aims to develop a new theory in order to complement the existing theories. In the metaethnographic, the approach is interpretive of the results of primary research studies. Because the approach is interpretive, then the analysis is iterative technique (spiral). The results of primary research studies are reinterpreted (reinterpretation) so as to produce an understanding or a new theory by cross-thematic analysis iteratively so that between the extraction and analysis is non-linear sequential.

The meta-ethnography qualitative approach is originally introduced by Noblit \& Hare in 1988 and described as an attempt to develop a synthesis model of knowledge that is inductive interpretive (Britten et al, 2002; Noblit \& Hare, 1988; Tuquero, 2011). This method may be an explicit form of an interpretive review that is most commonly used (Greenwood \& Mackenzie, 2010). Meta- ethnography approach is conducted by describing and integrating a cross-study to generate new understanding and perspective (McDermott et al, 2004). Meta-ethnographic approach consists of seven steps (Noblit \& Hare, 1988) as described in Table 2.

Meta-ethnography allows taking a concept that is often implicit to be linked together and organized into a theoretical model that has a new meaning (Greenwood \& Mackenzie, 2010).

In this study, used a meta-ethnographic qualitative approach in formulating and proposing a maturity model based on the new e-Government portal from the result of the synthesis carried out.

\section{RESULT AND DISCUSSION}

As mentioned earlier that until now, there have been a lot of maturity models based on e-Government portal which has been developed both by individuals like Layne \& Lee (2001: 124) as well as by institutions like Gartner (2000: 3). Here is presented the list of maturity models based on e-Government portal that exist today and most widely used as a reference (Layne \& Lee, 2001; Andersen \& Henriksen, 2006; United Nations, 2012; Alhomod et al., 2012; Hiller \& Belanger 2001; Almazan \& Gil-Garcia, 2008; Cisco 2007; Gartner Group, 2000; West, 2004; Moon, 2002; World Bank, 2003; Deloitte \& Touche, 2000; Howard, 2001; Shahkooh et al., 2008; Lee and Kwak, 2012 ; Siau \& Long, 2005; Wescott, 2001; Chandler \& Emanuel, 2002; Kim and Grant, 2010; Chen et al., 2011; Windley, 2002; Reddick, 2004; Accenture, 2003; The UK National Audit Office, 2002 and Netchaeva, 2002). The list of maturity models based on e-Government portal becomes the synthesis process materials in which overall earned 25 studies related to maturity models based on e-Government portal that can be presented in Table 3 .

In Table 3, can be seen that indeed there are 
Table 3.

Maturity Model Based on e-Government Portal

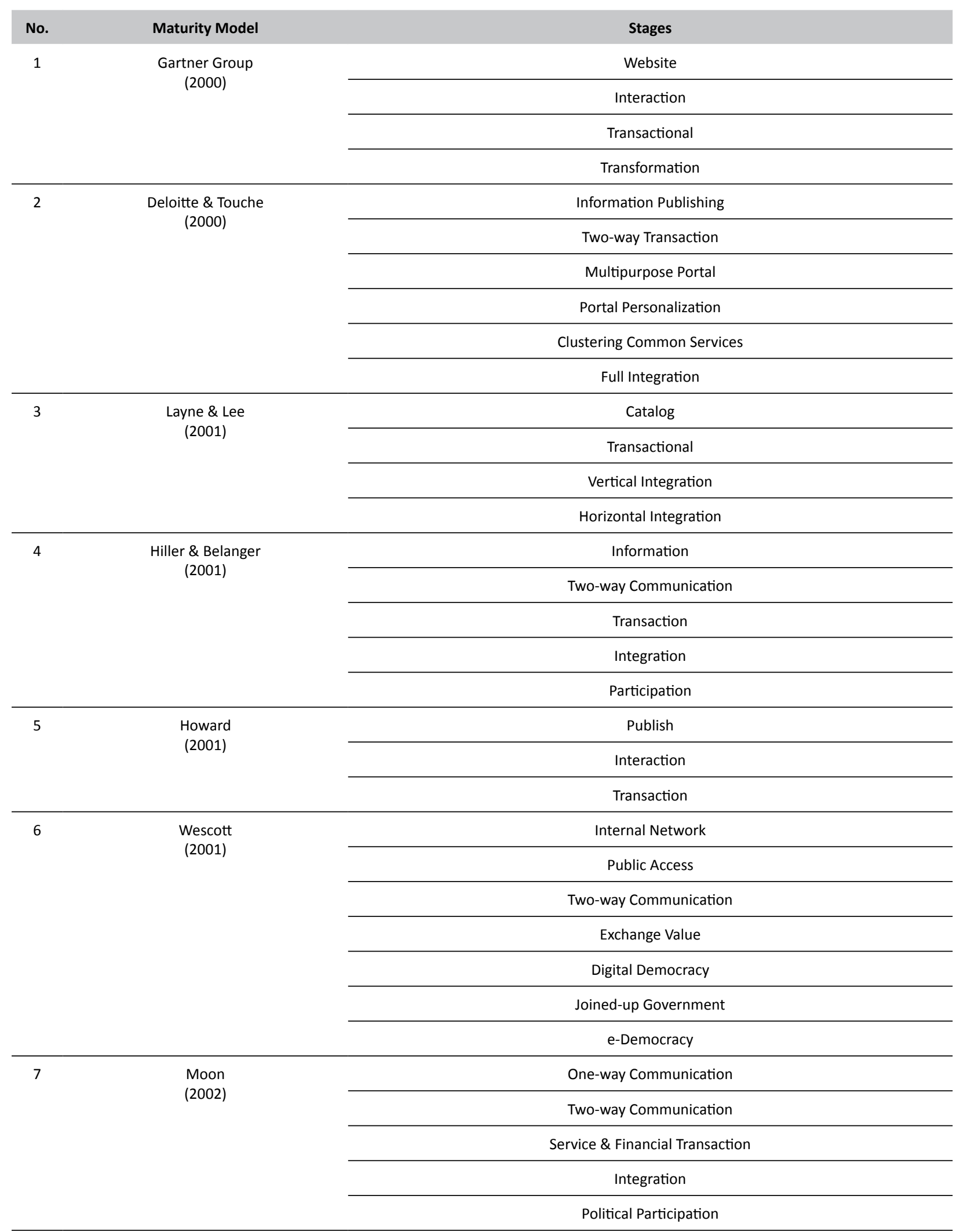




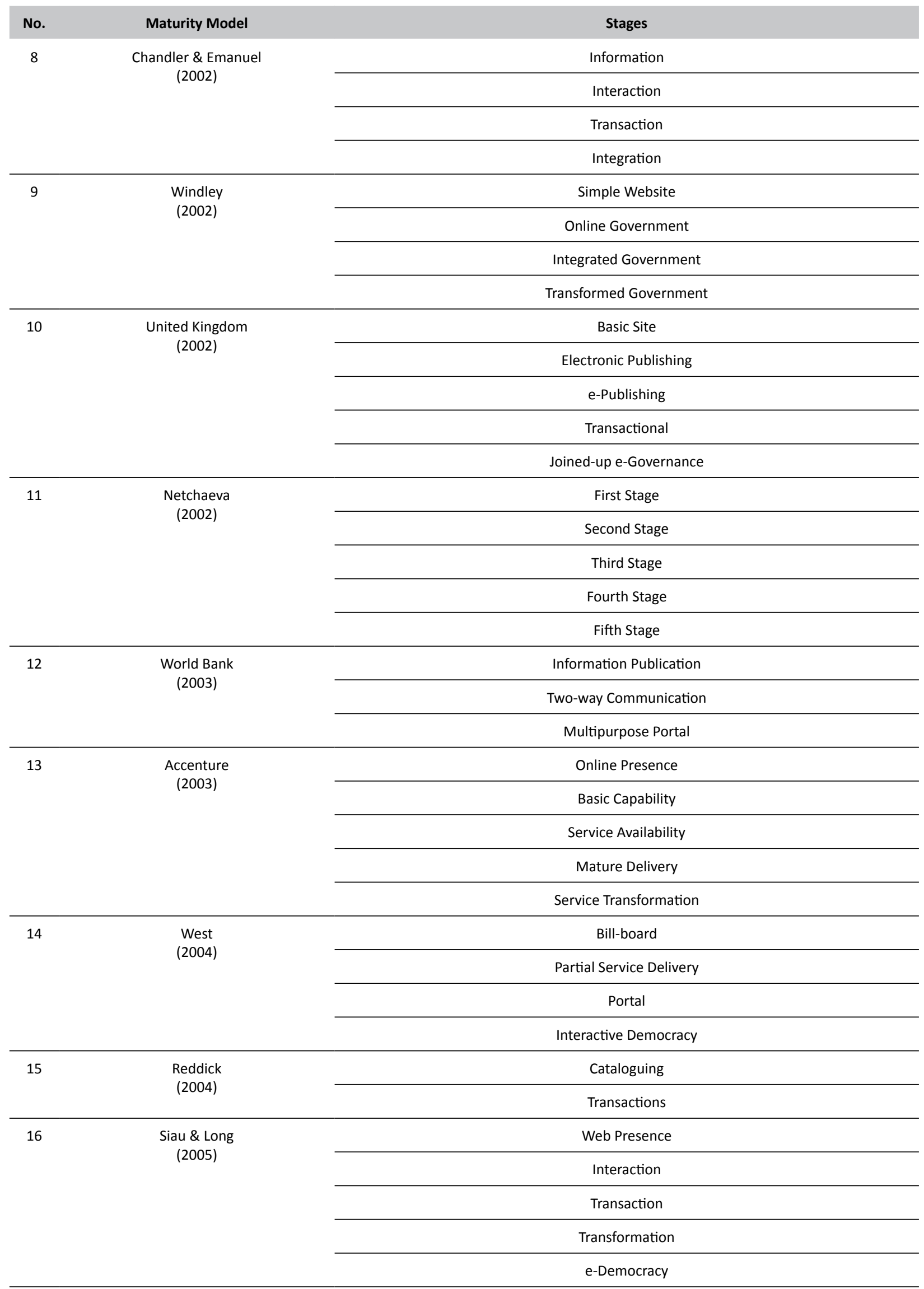




\begin{tabular}{|c|c|c|}
\hline No. & Maturity Model & Stages \\
\hline \multirow[t]{4}{*}{17} & \multirow{4}{*}{$\begin{array}{l}\text { Andersen \& Henriksen } \\
\qquad(2006)\end{array}$} & Cultivation \\
\hline & & Extension \\
\hline & & Maturity \\
\hline & & Revolution \\
\hline \multirow[t]{3}{*}{18} & \multirow{3}{*}{$\begin{array}{l}\text { Cisco } \\
(2007)\end{array}$} & Information Interaction \\
\hline & & Transaction Efficiency \\
\hline & & Transformation \\
\hline \multirow[t]{5}{*}{19} & \multirow{5}{*}{$\begin{array}{l}\text { Shahkooh } \\
(2008)\end{array}$} & Online Presence \\
\hline & & Interaction \\
\hline & & Transaction \\
\hline & & Fully Integrated \& Transformed e-Government \\
\hline & & Digital Democracy \\
\hline \multirow[t]{6}{*}{20} & \multirow{6}{*}{$\begin{array}{l}\text { Almazan \& Gil-Garcia } \\
\text { (2008) }\end{array}$} & Website \\
\hline & & Information \\
\hline & & Interaction \\
\hline & & Transaction \\
\hline & & Integration \\
\hline & & Political Participation \\
\hline \multirow[t]{5}{*}{21} & \multirow{5}{*}{$\begin{array}{c}\text { Kim \& Grant } \\
\text { (2010) }\end{array}$} & Web Presence \\
\hline & & Interaction \\
\hline & & Transaction \\
\hline & & Integration \\
\hline & & Continuous Improvement \\
\hline \multirow[t]{3}{*}{22} & \multirow{3}{*}{$\begin{array}{l}\text { Chen } \\
(2011)\end{array}$} & Catalogue \\
\hline & & Transaction \\
\hline & & Vertical Integration \\
\hline \multirow[t]{4}{*}{23} & \multirow{4}{*}{$\begin{array}{l}\text { United Nations } \\
\qquad(2012)\end{array}$} & Emerging Information \\
\hline & & Enhanced Information Services \\
\hline & & Transactional services \\
\hline & & Connected services \\
\hline \multirow[t]{4}{*}{24} & \multirow{4}{*}{$\begin{array}{l}\text { Alhomod } \\
(2012)\end{array}$} & Website \\
\hline & & Interaction \\
\hline & & Transaction \\
\hline & & Service Integration \\
\hline \multirow[t]{5}{*}{25} & \multirow{5}{*}{$\begin{array}{l}\text { Lee \& Kwak } \\
\text { (2012) }\end{array}$} & Initial Conditions \\
\hline & & Data Transparency \\
\hline & & Open Participation \\
\hline & & Open Collaboration \\
\hline & & Ubiquitous Engagement \\
\hline
\end{tabular}


many researchers who formulated maturity models based on e-Government portal and the stages in it. However, the overall maturity models are still scattered in various journal articles and conferences. The studies have formulated a maturity model that are identified different from each other but do not provide a complete picture.

For example, Gartner Group (2000) has formulated a maturity model based on e-Government portal with 4 (four) stages, namely websites, interaction, transactional, and transformation. Moon (2002) has formulated a maturity model based on portal with five (5) stages, namely one-way communication, two-way communication, financial transaction and service, political integration and participation. Layne \& Lee (2001) have also formulated maturity model based on portal with four (4) stages namely catalog, transactional, vertical integration, and horizontal integration. These three studies are conducted at different times; the Gartner Group (2000), Layne \& Lee (2001), and Moon (2002).

If dug deeper, there are several stages in the model expressed by Gartner Group (2000: 3), Layne \& Lee (2001: 124), and Moon (2002: 428) that have the same meaning despite the name differences. For example, a study conducted by Gartner Group (2000) identifies one of the stages in the model, namely "website", but in a study conducted by Layne \& Lee (2001: 125), there is a model stage called the "catalog". While the research by Moon (2002: 428) mentions the step "one-way communication". Although all three stages have different names but basically the meaning of the three is the same, that is "Web Presence".

In addition, there are several stages in a maturity model, especially from the two studies (Gartner Group, 2000: 3; Moon, 2002: 428) that have the same meaning although the names are different. The "interaction" stage is formulated by Gartner Group (2000: 3) while the "two-way communication" stage is formulated by Moon (2002: 428). Both stages of the maturity model can be said to have the same meaning that is "Dynamic Interactive Web". Therefore, can be synthesized from those both articles to gain a generic maturity model of both.

But in the research by Layne \& Lee (2001: 124), there is no stage that refers to the "dynamic interactive Website". This confirms that some of the maturity model based on e-Government portal has different stages and ignore the stages of other models (Abdoullah et al., 2014: 87). This, of course, requires a synthesis technique to integrate.

The above examples are only from three journal articles. Once traced, there are still many other journal articles or conferences that have also formulated maturity models based on of
e-Government portal. In other words, the synthesis process is conducted on several journal articles or conferences that have been formulated based on maturity model of e-Government portal. The synthesis process in this study is conducted using a systematic review method through a qualitative approach or study called meta-ethnography approach. As mentioned earlier that the systematic review can be conducted with a qualitative approach. This means that the input of this research is a descriptive qualitative study that is synthesized into output in the form of maturity model based on e-Government portal with a qualitative analysis approach or a technique called meta-ethnography.

\section{A. A Synthesis Process of Meta- Ethnography: Maturity Model Based on e-Government Portal}

The following synthesis process refers to the previous section, namely Table 2 Seven Steps of Meta-Ethnography that can be described below:

\section{1) Preparation}

The topic of this research is to develop a maturity model based on e-Government portal with the Meta-Ethnography qualitative approach.

\section{2) Determining the Relevant Study}

The study relevant to the focus of this study is only associated significantly with the maturity model based on e-Government portal. As mentioned before, the whole articles in this study are mostly taken from reliable sources, which are various journals or conference articles that are indexed in Scopus (journal) and IEEE Xplore (conference). But there are also other sources involved to enrich this study so that a greater explanatory can be obtained from a variety of existing studies.

The result of the article searching can be presented in Table 4, in which gained a total of 25 articles which consist of 13 journal articles, 3 conference papers, and 9 other articles. The articles obtained are related to maturity models based on e-Government portal that exist today and most widely used as research references.

Table 4.

Result of Article Searching (Study) Based on Source

\begin{tabular}{cc} 
Source & Number of Artocles (Study) \\
\hline Scopus (Journal) & $13(52 \%)$ \\
\hline IEEE Xplore (Conference) & $3(12 \%)$ \\
\hline Others & $9(36 \%)$ \\
\hline Total & $\mathbf{2 5 ( 1 0 0 \% )}$
\end{tabular}


Table 5.

Translation and Synthesis Results

\begin{tabular}{|c|c|c|c|c|c|c|c|}
\hline \multicolumn{8}{|c|}{ Maturity Stages Code } \\
\hline No. & A & B & C & D & E & $\mathbf{F}$ & G \\
\hline 1 & 1.1 & 1.2 & 1.3 & - & - & 1.4 & - \\
\hline 2 & 2.1 & 2.2 & 2.3 & 2.4 & 2.5 & 2.6 & - \\
\hline 3 & 3.1 & 3.1 & 3.2 & 3.3 & 3.4 & - & - \\
\hline 4 & 4.1 & 4.2 & 4.3 & - & - & 4.4 & 4.5 \\
\hline 5 & 5.1 & 5.2 & 5.3 & - & - & - & - \\
\hline 6 & $\begin{array}{l}6.1 \\
6.2\end{array}$ & 6.3 & 6.4 & - & - & 6.6 & 6.5 \\
\hline 7 & 7.1 & 7.2 & 7.3 & - & - & 7.4 & 7.5 \\
\hline 8 & 8.1 & 8.2 & 8.3 & - & - & 8.4 & - \\
\hline 9 & 9.1 & 9.2 & 9.3 & - & - & 9.4 & - \\
\hline 10 & $\begin{array}{l}10.1 \\
10.2\end{array}$ & 10.3 & 10.4 & - & - & 10.5 & - \\
\hline 11 & 11.1 & $\begin{array}{l}11.2 \\
11.3\end{array}$ & 11.4 & - & - & - & 11.5 \\
\hline 12 & 12.1 & 12.2 & 12.3 & - & - & - & - \\
\hline 13 & 13.1 & 13.2 & 13.3 & - & - & $\begin{array}{l}13.4 \\
13.5\end{array}$ & - \\
\hline 14 & 14.1 & 14.2 & 14.3 & - & - & - & 14.4 \\
\hline 15 & 15.1 & 15.1 & 15.2 & - & - & - & - \\
\hline 16 & 16.1 & 16.2 & 16.3 & - & - & 16.4 & 16.5 \\
\hline 17 & 17.1 & 17.2 & - & - & - & $\begin{array}{l}17.3 \\
17.4\end{array}$ & - \\
\hline 18 & 18.1 & 18.1 & 18.2 & - & - & 18.3 & - \\
\hline 19 & 19.1 & 19.2 & 19.3 & - & - & 19.4 & 19.5 \\
\hline 20 & $\begin{array}{l}20.1 \\
20.2\end{array}$ & 20.3 & 20.4 & - & - & 20.5 & 20.6 \\
\hline 21 & 21.1 & 21.2 & 21.3 & - & - & 21.4 & 21.5 \\
\hline 22 & 22.1 & 22.1 & 22.2 & 22.3 & - & - & - \\
\hline 23 & 23.1 & 23.2 & 23.3 & - & - & 23.4 & - \\
\hline 24 & 24.1 & 24.2 & 24.3 & - & - & 24.4 & - \\
\hline 25 & 25.1 & 25.2 & - & - & - & 25.5 & $\begin{array}{l}25.3 \\
25.4\end{array}$ \\
\hline
\end{tabular}

\section{3) Read and Review the Study}

In the study by Noblit \& Hare (1988), stated that it may appear a few key concepts from the existing studies using meta-ethnography. But in this study, the researcher only focus on a key concept, namely the stages of maturity models. At this stage, the researcher repeatedly reads and reviews a total of 25 existing studies, then the researcher gives and marks a key concept (metaphor) in which there are 111 key concepts derived from the overall 25 existing studies.

\section{4) Determine Inter-Study Relations}

In this phase, the researcher follows what was suggested (Noblit \& Hare 1988), which is creating a table that contains the key concepts of all 25 existing studies. The list of concepts of 25 studies 
can be seen in Table 3, but each of the key concepts of the study is given the identity in the form of numbers to facilitate the translation process. For example, the key concepts of Gartner Group's study (2000) namely Website (1.1), Interactions (1.2), Transactional (1.3) and Transformation (1.4). Similarly, the concept of the study by Deloitte \& Touche (2000), namely Information publishing (2.1), Two-way transaction (2.2), Multipurpose Portal (2.3), Portal personalization (2.4), Clustering Common Services (2.5) and Full integration (2.6). The provision of this number identity applies to the whole concept of the existing studies based on serial numbers in Table 3.

At this stage, the researcher also conducts a comparison between the concepts that surface across the studies. It can be said that the concept of the existing studies is directly comparable and turns out many of the concepts are similar to each other; therefore, all studies are related or the relations are assumed in the form of reciprocal translation (Edwards et al., 2009; Noblit \& Hare, 1988). This means that there are not or not found the concepts that contradict one another. The overall concepts that have been identified in this study have a resemblance or similarity of meaning.

\section{5) Translate Each Other Studies (translation)}

As suggested by Noblit \& Hare (1988: 53) that in practice some of the steps in the Meta-Ethnographic can overlap and run in parallel. Therefore, in this study, the fifth stage or phase (translation) and sixth stage or phase (synthesis) can be performed simultaneously. At this stage, the researcher also continues to consider the explanations of each study of maturity model based on e-Government portal, especially on stages. For example, Deloitte \& Touche (2000: 12) state that one of the stages in the maturity model based on e-Government portal is "Information publishing" in which the explanation of this concept is that every government agency sets up a website to provide information regarding the institutional. Meanwhile, the United Nations (2012) formulates the model stage that is "emerging information" where the explanation of this concept is basic information and static from the government that is presented through the official website. World Bank (2003) also formulates a model of its maturity stage, namely "publish" in which the explanation is the useful information for the public provided by the government through the website. From the above examples, it can be seen that the three concepts are derived from three studies that discuss the same idea that is "the availability of information by the government via the website". This also applies to other studies that describe a similar idea. In the case of this translation, taking into account the explanations of each concept stage contained in the
Table 6.

Tahapan e-Government Maturity Model Berbasis Portal

\begin{tabular}{cc} 
Kode & Tahapan Maturity (Maturity Stage) \\
A & Web Presence (Kehadiran Website) \\
\hline B & Interaction (Web Interaktif) \\
\hline C & Transaction (Web Transaksional) \\
\hline D & Vertical Integration (Integrasi Vertikal) \\
\hline E & Horizontal Integration (Integrasi Horizontal) \\
\hline F & Full Integration (Integrasi e-Portal) \\
\hline G & Open Participation (Partisipasi Terbuka) \\
\hline
\end{tabular}

study, the researchers synthesize into a new concept of "Presence website (Web Presence)". Researchers incorporate the concept of this synthesis results become one of the stages of maturity model-based e-Government portal. In the same way with the example above, the researchers conducted the process of translation and synthesis to all existing concepts. In this process, there are many similarities in meanings of existing concepts as well as the discovery of several concepts in a model that can be categorized in one stage of maturity models such as the concept 10.1 (basic site) and 10.2 (electronic publishing), which has the meaning of information submitted electronically through the website. Both concepts can be translated and synthesized into a new stage model of "Web Presence".

As a result, from this process produces five concepts synthesized as in Table 5.

\section{6) Synthesis of Translation Result and Synthesis of Expression}

At this stage, stated a form of expression from the results of the synthesis that has been conducted before (Table 5). In the table, the row in the table shows the study while the column in the table shows the stages of synthesized maturity models. The whole five stages of e-Government maturity models based on portal resulted from the synthesis process are expressed as shown in Table 6.

Based on Table 6, can be described the main stages in the maturity model based on e-Government portal that consists of:

1. Stage 1 is the Web Presence. At this stage, the government begins to display information to public online.

2. Stage 2 is Interaction (interactive web). At this stage, the information provided is dynamic and provides an interaction space with public through e-mail, downloadable forms, and search facilities.

3. Stage 3 is the Transaction (web transactional). At this stage, the government is providing facilities for public to be able to conduct online 
transactions such as payments, tax filing, license renewal, the procurement of goods and services, etc.

4. Stage 4 is the Vertical Integration. At this stage, the integration of data and system among government agencies that have the same function vertically, e.g. level-one local governments (province) and level-two (regency/city).

5. Stage 5 is Horizontal Integration (horizontal integration). At this stage. it carried out the integration of data and system among government agencies that have different functions (cross-agency) e.g. regency/city governments and trading agencies in licensing terms such as SIUP, etc.

6. Stage 6 is the Full Integration (thorough integration of e-Portal). At this stage, government services are fully integrated into one door via e-Portal.

7. Stage 7 is Open Participation (open participation). At this stage, available space for public to participate in the formulation of state policy (e-Participation) and the election of heads of regions/countries (e-Voting).

\section{Conclusion}

Based on the research that has been conducted, can be concluded a number of conclusions and recommendations as follows:

1. There are seven (7) stages of maturity model based on e-Government portal, namely web presence, interaction, transaction, vertical integration, horizontal integration, full integration, and open participation. Maturity models obtained is the result of the synthesis process through re-interpretation towards the existing model so that the resulting model is more holistic (whole) and generic. Stages produced are also detailed so as to provide a clear understanding and easiness for government agencies to achieve. The linkage between the seven stages of the deployment phase to be passed is started from the first phase (web presence), then interaction, and so on.

2. Maturity model consisting of these seven stages is a contribution from the research, which is a synthesis of 25 maturity model based on e-Government portal (best practice) that exists today.

3. This research resulted in a maturity model based on portal that can be used to measure the maturity level of the implementation of e-Government system in Indonesia.

4. The meta-ethnographic qualitative approach is successfully used to build a maturity model based on e-Government portal.
5. The policy recommendation to the government is to adopt a maturity model that is generated in this study as a reference for the phase of development of e-Government in Indonesia. This can take the form of Presidential Instruction as before (Inpres No. 3 of 2003) the guidelines for government agencies in implementing e-government system in Indonesia.

6. The suggestion in this study as a follow-up study is the validation of conceptual maturity model empirically so as to support the widespread acceptance of the model. This can be done with a survey to several government agencies (best practices) that are sampled to confirm the level of agreement on each existing stage based on the perspective of government agencies.

\section{ACKNOWLEDGEMENT}

The author would like to express his gratitude for P2SMTP-LIPI for providing the technical assistance and facility as well as the e-Government laboratory in Faculty of Computer Science of Universitas Indonesia for the conceptual contribution so that the author could finish this research properly.

\section{REFERENCES}

Alhomod, S. \& Shafi, M. (2012). Best Practices in E-Government: A Review of Some Innovative Models Proposed in Different Countries. International Journal of Electrical \& Computer Sciences IJECS-IJENS, 12(1), 1-6. Retrieved from http://www.ijens.org/IJECS\%20Vol\%20 12\%20Issue\%2001.html.

Almazan, R. \& Gil-Garcia, J. E-Government Portals in Mexico. Electronic Government, 1726-1734. http://dx.doi.org/10.4018/978-1-59904-9472.ch131.

Andersen, K. \& Henriksen, H. (2006). E-Government Maturity Models: Extension of the Layne and Lee Model. Government Information Quarterly, 23(2), 236-248. http://dx.doi.org/10.1016/j. giq.2005.11.008.

At the Dawn of e-Government: The Citizen as Customer. (2000). New York, NY.

Baum, C. \& Maio, A. (2016). Gartner's Four Phases of E-Government Model. Gartner.com. Retrieved from https://www.gartner.com/doc/317292/ gartners-phases-egovernment-model.

Chandler, S. \& Emanuels, S. (2002). Transformation Not Automation. In Proceedings of 2nd European Conference on E-Government (pp. 91-102). Oxford, UK: St. Catherine's College.

Chen, H. (2002). Digital Government: Technologies and Practices. Decision Support Systems, 34(3), 
223-227.

Chen, J., Yan, Y., \& Mingins, C. (2011). A Three-Dimensional Model for E-Government Development with Cases in China's Regional E-Government Practice and Experience. In 2011 International Conference on Management of e-Commerce and e-Government (pp. 113-120). Los Alamitos: IEEE Computer Society.

Davies, P. (2008). e-Government Best Practices Learning from Success, Avoiding the Pitfalls. Presentation, World Bank.

Fath-Allah, A., Cheikhi, L., Al-Qutaish, R., \& Idri, A. (2014). E-Government Maturity Models: A Comparative Study. International Journal of Software Engineering \& Applications (IJSEA), 5(3), 71-91. Retrieved from http://www.airccse.org/journal/ijsea/vol5.html.

Furuholt, B. \& Wahid, F. (2008). E-Government Challenges and the Role of Political Leadership in Indonesia: The Case of Sragen. In Proceedings of the 41st Annual Hawaii International Conference on System Sciences (HICSS 2008) (p. 411). Los Alamitos: IEEE Computer Society.

Government on the Web II - National Audit Office (NAO). (2016). National Audit Office. Retrieved from https://www.nao.org.uk/report/government-on-the-web-ii/.

Green, S. (2005). Systematic Reviews and Meta-Analysis. Singapore Med J, 46(6), 270-274.

Greenwood, N. \& Mackenzie, A. (2010). Informal Caring for Stroke Survivors: Meta-ethnographic Review of Qualitative Literature. Maturitas, 66(3), 268-276. http://dx.doi.org/10.1016/j. maturitas.2010.03.017.

Hammond, N. \& Perry, A. (2002). Systematic Reviews: The Experiences of a PhD Student. Psychology Learning \& Teaching, 2(1), 32-35. http://dx.doi.org/10.2304/plat.2002.2.1.32.

Hiller, J. \& Bélanger, F. (2001). Privacy Strategies for Electronic Government. Arlington, VA: The Pricewaterhouse Coopers Endowment for the Business of Government.

Howard, M. (2001). E-Government across the Globe: How Will "E” Change Government. Government Finance Review, (4).

Ifinedo, P. \& Singh, M. (2011). Determinants of eGovernment Maturity in the Transition Economies of Central and Eastern Europe. Electronic Journal Of E-Government, 9(2), 166-182. Retrieved from http://www.ejeg.com/volume9/issue2.

Istiyanto, J. \& Sutanta, E. (2012). Model Interoperabilitas Antar Aplikasi E-Government. Jurnal Teknologi Technoscientia, 4(2), 137-148. Retrieved from http://technoscientia.akprind. ac.id/techno/media.php?act=journalokabs?1082.

Jaya, S. (2013). Implementasi dan Perkembangan E-Government di Indonesia. Jurnal Informatika
Multimedia (JIM), 2(1), 37-52. Retrieved from http://jim.stimednp.ac.id/.

Jupp, V. \& Rohleder, S. (2003). eGovernment Leadership: Engaging the Customer. Accenture.

Kim, D. \& Grant, G. (2010). E-Government Maturity Model Using the Capability Maturity Model Integration. Journal of Systems And Information Technology, 12(3), 230-244. http://dx.doi.org/http://dx.doi. org/10.1108/13287261011070858.

Kitchenham, B. (2004). Procedures for Performing Systematic Reviews.

Kondisi Situs Web Pemerintah Daerah. (2009). Depkominfo. Retrieved from http://www.depkominfo.go.id.

Layne, K. \& Lee, J. (2001). Developing Fully Functional E-Government: A Four Stage Model. Government Information Quarterly, 18(2), 122-136. http://dx.doi.org/10.1016/S0740624X(01)00066-1.

Lee, G. \& Kwak, Y. (2012). An Open Government Maturity Model for Social Media-Based Public Engagement. Government Information Quarterly, 29(4), 492-503. http://dx.doi.org/10.1016/j. giq.2012.06.001.

Lehmkuhl, T., Baumöl, U., \& Jung, R. (2013). Towards a Maturity Model for the Adoption of Social Media as a Means of Organizational Innovation. In 2013 46th Hawaii International Conference on System Sciences (pp. 3067-3076). Grand Wailea, Maui, Hawaii: Conference Publishing Services. Retrieved from http://dx.doi. org/10.1109/HICSS.2013.561.

Lewin, S. (2008). Methods to Synthesise Qualitative Evidence Alongside a Cochrane Intervention Review. London: London School of Hygiene and Tropical Medicine.

McDermott, E., Graham, H., \& Hamilton, V. (2004). Experiences of being A Teenage Mother in the UK: A Report of a Systematic Review of Qualitative Studies. Glasgow: University of Glasgow. Social and Public Health Services Unit.

Moon, M. (2002). The Evolution of E-Government among Municipalities: Rhetoric or Reality?. Public Administration Review, 62(4), 424-433. http://dx.doi.org/10.1111/0033-3352.00196.

Napitupulu, D. (2015). Kajian Faktor Sukses Implementasi E-Government Studi Kasus: Pemerintah Kota Bogor. Jurnal Sistem Informasi, 5(3), 229-236. Retrieved from http://id.portalgaruda.org/?ref=browse \&mod=viewarticle \&article $=313616$.

Netchaeva, I. (2002). E-Government and E-Democracy: A Comparison of Opportunities in the North and South. International Communication Gazette, 64(5), 467-477. http://dx.doi.org/10. $1177 / 17480485020640050601$.

Nilashi, M., Bagherifard, K., Ibrahim, O., Janahmadi, 
N., \& Alizadeh, H. (2012). A Multi-Criteria Approach to the Evaluation of Malaysian Government Portal. Journal of Theoretical And Applied Information Technology, 40(2), 194-201.

Noblit, G. \& Hare, R. (1988). Meta-Ethnography Synthesizing Qualitative Studies. Newbury Park, Calif.: Sage Publications.

Obi, T. (2015). 2015 Waseda - IAC International E-Government Ranking Survey. Tokyo: Institute of e-Government, Waseda University. Retrieved from http://e-gov.waseda.ac.jp/pdf/2015 Waseda_IAC_E-Government_Press_Release. pdf.

Paulk, M., Curtis, B., Chrissis, M., \& Weber, C. (1993). Capability Maturity Model for Software, Version 1.1. Pittsburgh, Pennsylvania: Carnegie Mellon University.

Paulk, M., Weber, C., Curtis, B., \& Chrissis, M. (1996). The Capability Maturity Model: Guidelines for Improving the Software Process. Estados Unidos: Addison-Wesley.

PeGI Tingkat Provinsi pada Tahun 2014. (2014). Retrieved from http://pegi.layanan.go.id/download/tabel_pegi_2014/HASIL\%20PROVINSI\%202014.bmp.

Reddick, C. (2004). A Two-Stage Model of E-Government Growth: Theories and Empirical Evidence for U.S. Cities. Government Information Quarterly, 21(1), 51-64. http://dx.doi. org/10.1016/j.giq.2003.11.004.

Ronaghan, S. (2002). Benchmarking E-government: A Global Perspective. New York: United Nations-DPEPA \& ASPA. Retrieved from https:// publicadministration.un.org/egovkb/Portals/ egovkb/Documents/un/2010-Survey/Complete-survey.pdf.

Shahkooh, K., Saghafi, F., \& Abdollahi, A. (2008). A Proposed Model for E-government Maturity. In Information and Communication Technologies: From Theory to Applications. Damascus, Syiria: IEEE.

Siau, K.\& Long,Y.(2005). Synthesizing E-Government Stage Models - A Meta-Synthesis Based on MetaEthnography Approach. Industrial Management \& Data Systems, 105(4), 443-458. http:// dx.doi.org/10.1108/02635570510592352.

Siswanto,. (2010). Systematic Review Sebagai Metode Penelitian untuk Mensintesis Hasil-hasil Penelitian (Sebuah Pengantar). Buletin Penelitian Sistem Kesehatan, 13(4), 326-333. Retrieved from http://ejournal.litbang.depkes. go.id/index.php/hsr/article/view/2766.
Tabel Hasil PeGI | Pemeringkatan e-Government Indonesia (PeGI). (n.d.). Retrieved from http:// pegi.layanan.go.id/tabel-hasil-pegi-4/.

Tuquero, J. (2011). A Meta-Ethnographic Synthesis of Support Services in Distance Learning Programs. Journal of Information Technology Education, 10, 157-179. Retrieved from http:// eric.ed.gov/?id=EJ940910.

UN E-Government Survey 2012: E-Government for the People. (2012). New York. Retrieved from https://publicadministration.un.org/egovkb/ Portals/egovkb/Documents/un/2012-Survey/unpan048065.pdf.

UN E-Government Survey 2014: E-Government for the Future We Want. (2014). New York. Retrieved from https://publicadministration. un.org/egovkb/Portals/egovkb/Documents/ un /2014-Survey/E-Gov_Complete_Survey-2014.pdf.

Wescott, C. (2001). E-Government in the Asia-pacific region. Asian Journal of Political Science, 9(2), 1-24. http://dx.doi. org/10.1080/02185370108434189.

West, D. (2004). E-Government and the Transformation of Service Delivery and Citizen Attitudes. Public Administration Review, 64(1), 15-27. http://dx.doi.org/10.1111/j.15406210.2004.00343.x.

West, D. (2007). Global E-Government, 2007 (pp. 1-25). Providence, Rhode Island: Center for Public Policy Brown University. Retrieved from http://www.insidepolitics.org/egovt07int.pdf.

Widiatmoko, H. (2009). E-Government di Indonesia: Content Analysis Situs Web Pemerintah Daerah (Master Thesis). Universitas Indonesia.

Windley, P. (2002). eGovernment Maturity. Utah: State of Utah. Retrieved from http://www. windley.com/docs/eGovernment\%20Maturity.pdf.

World Development Indicators 2003: World Development Indicators. (2016). Elibrary.worldbank. org. Retrieved from http://elibrary.worldbank. org/doi/abs/10.1596/0-8213-5422-1.

World Report on Knowledge for Better Health: Strengthening Health Systems. (2016). Geneva. Retrieved from http://www.who.int/rpc/ meetings/en/world_report_on_knowledge_ for_better_health2.pdf.

Yalia, M. (2011). Menuju Pelayanan Publik Yang Lebih Baik dengan E-Government. Buletin $\mathrm{Ob}$ servasi, 9(2), 63-74. 